\title{
Whole-brain glutamate metabolism evaluated by steady-state kinetics using a double-isotope procedure: effects of gabapentin
}

\author{
Y. Xu, ${ }^{*}$ G. Öz,† K. F. LaNoue,* C. J. Keiger, $†$ D. A. Berkich, ${ }^{*}$ R. Gruetter† and S. H. Hutson \\ * Departments of Cellular and Molecular Physiology, Pennsylvania State University College of Medicine, Hershey, Pennsylvania, USA \\ $\dagger$ Department of Radiology, University of Minnesota Medical School, Minneapolis, Minnesota, USA \\ \$ Department of Biochemistry, Wake Forest University School of Medicine, Winston-Salem, North Carolina, USA
}

\begin{abstract}
Cerebral rates of anaplerosis are known to be significant, yet the rates measured in vivo have been debated. In order to track glutamate metabolism in brain glutamatergic neurons and brain glia, for the first time unrestrained awake rats were continuously infused with a combination of $\mathrm{H}^{14} \mathrm{CO}_{3}{ }^{-}$and $\left[1-{ }^{13} \mathrm{C}\right]$ glucose in over 50 infusions ranging from 5 to $60 \mathrm{~min}$. In whole-brain extracts from these animals, the appearance of ${ }^{14} \mathrm{C}$ in brain glutamate and glutamine and appearance of ${ }^{13} \mathrm{C}$ in the $\mathrm{C}-4$ position of glutamate and glutamine were measured as a function of time. The rate of total neuronal glutamate turnover, the anaplerotic rate of synthesis of glutamine and glutamate from $\mathrm{H}^{14} \mathrm{CO}_{3}^{-}$, flux through the glutamate/glutamine cycle, and a minimum estimate of whole-brain anaplerosis was obtained. The rate of synthesis of ${ }^{14} \mathrm{C}$-glutamate from $\mathrm{H}^{14} \mathrm{CO}_{3}{ }^{-}$was $1.29 \pm 0.11 \mathrm{nmoles} / \mathrm{min} / \mathrm{mg}$ protein, whereas the rate of synthesis of ${ }^{14} \mathrm{C}$-glutamine was $1.48 \pm 0.10 \mathrm{nmoles} / \mathrm{min} / \mathrm{mg}$ protein compared to total glutamate turnover of $9.39 \pm 0.73 \mathrm{nmoles} / \mathrm{min} / \mathrm{mg}$ protein .
\end{abstract}

From the turnover rate of glutamine, an upper limit for flux through the glutamate/glutamine cycle was estimated at $4.6 \mathrm{nmoles} / \mathrm{min} / \mathrm{mg}$ protein. Synthesis of glutamine from $\mathrm{H}^{14} \mathrm{CO}_{3}{ }^{-}$was substantial, amounting to $32 \%$ of the glutamate/ glutamine cycle. These rates were not significantly affected by a single injection of $100 \mathrm{mg} / \mathrm{kg}$ of the antiepileptic drug gabapentin. In contrast, acute administration of gabapentin significantly lowered incorporation of $\mathrm{H}^{14} \mathrm{CO}_{3}{ }^{-}$into glutamate and glutamine in excised rat retinas, suggesting metabolic effects of gabapentin may require chronic treatment and/or are restricted to brain areas enriched in target enzymes such as the cytosolic branched chain aminotransferase. We conclude that the brain has a high anaplerotic activity and that the combination of two tracers with different precursors affords unique insights into the compartmentation of cerebral metabolism.

Keywords: brain, gabapentin, glutamate/glutamine cycle, glutamatergic neurons, pyruvate carboxylase, retina.

J. Neurochem. (2004) 90, 1104-1116.
Glutamate (along with aspartate) is the major excitatory neurotransmitter in the mammalian brain (Fonnum 1984; Takahashi et al. 1997). This amino acid is unusual, because it has a dual role, first as a neurotransmitter and, second, as an important intermediate of nitrogen metabolism (LaNoue and Tischler 1974; Schoolwerth et al. 1977; Strzelecki et al. 1988; Sterniczuk et al. 1991; Sonnewald et al. 1993). Its role as an intermediate in nitrogen metabolism and in energy production in peripheral tissues is well recognized, but the relationship between its metabolism and its neurotransmitter function has received less attention.

Glutamate in its role as neurotransmitter is released from nerve endings of glutamatergic nerves (Torgner and Kvamme 1990) and from photoreceptor cells in the retina (Mimura et al. 2002). It signals to post-receptor neurons via various subclasses of glutamate receptors (Michaelis 1998). To clear it from the synaptic space, stop the signal, and to prevent neurotoxicity due to continued signaling, glutamate is rapidly transported into astrocytes that surround the glutamatergic synapses (Shousboe et al. 1993; Rothstein et al. 1994; Chaudhry et al. 1995; Derouiche 1996). Glutamate transporters in these astrocytes use the plasma membrane $\mathrm{Na}^{+}$

Received March 10, 2004; revised manuscript received April 19, 2004; accepted April 20, 2004.

Address correspondence and reprint requests to Kathryn F. LaNoue, Cellular and Molecular Physiology, 500 University Drive, H166, Hershey, PA 17033, USA. E-mail: klanoue@psu.edu

Abbreviations used: BCATc and BCATm, branched chain aminotransferases; i.p., intraperitoneal. 
gradient as a source of energy to maintain high glutamate gradients (in/out) across the glial plasma membrane (Kanai et al. 1993). To return the glutamate carbon skeleton to the neurons, glutamate is converted to glutamine via ATPdependent glutamine synthetase, exclusively expressed in the astrocyte cytosol (Martinez-Hernandez et al. 1977; Berl and Clarke 1983). Glutamine leaves the astrocytes and is taken up by neurons where glutaminase regenerates glutamate, which completes the well-known glutamate/glutamine cycle (Shank et al. 1985; Shousboe et al. 1993). As originally formulated, the glutamate/glutamine cycle hypothesis (van den Berg and Garfinkel 1971; Benjamin and Quastel 1974; Shank et al. 1985; Cooper and Plum 1987) provided an explanation for previous data (Berl et al. 1962, 1970, 1978) demonstrating that glutamate in the brain is highly compartmentalized and that a small, rapidly turning over compartment synthesizes glutamine from glutamate.

For some years, after the existence of the cycle was verified, glutamate's role as an intermediary metabolite in the brain was largely ignored. It was assumed that after entry into the glia from the neurons it was stochiometrically converted to glutamine, possibly after equilibration with $\alpha$-ketoglutarate. However, when glutamate exchanges its $\alpha$-amino nitrogen to become $\alpha$-ketoglutarate it is likely to be consumed in the citric acid cycle. Glutamate is the substrate of numerous transaminases and donates its nitrogen to $\alpha$-keto acids to form most other dispensable amino acids (Strzelecki et al. 1988; Sterniczuk et al. 1991; Sonnewald et al. 1993). Similarly $\alpha$-ketoglutarate is the major $\alpha$-keto acid acceptor in the breakdown of amino acids. Thus, in the brain, glutamate is obligatorily involved in amino acid synthesis and degradation as well as in neurotransmission. Neurons experience a constant loss of glutamate via neurotransmission. If glutamate were not returned to neurons rapidly enough, the loss would be compensated by conversion of neuronal $\alpha$ ketoglutarate to glutamate but the neuronal citric acid cycle would be depleted of cycle intermediates and ATP synthesis would stop. On the other hand, astrocytes experience a steady influx of glutamate carbon from glutamatergic neurotransmission. The glutamate may be converted to $\alpha$ ketoglutarate, potentially increasing the supply of citric acid cycle intermediates. Too rapid oxidation of glutamate via $\alpha-$ ketoglutarate in the astrocytic compartment could compromise the supply of glutamine to the neurons and possibly slow neuronal ATP synthesis. Too little oxidation might produce an excess of astrocytic glutamate and impair transport of glutamate into the astrocytes from the synaptic space. It is therefore important to understand how the level of $\alpha$-ketoglutarate and other citric acid cycle intermediates are regulated and maintained.

The presence of such regulatory mechanisms is supported by the observation that all enzymes required are expressed in astrocytes (Patel 1989; Schmoll et al. 1995; Cruz et al. 1998). To prevent an overaccumulation of $\alpha$-ketoglutarate, astrocytes express enzymes that can decarboxylate the citric acid cycle intermediates from 4-carbon to 3-carbon intermediates forming pyruvate from glutamate (Sonnewald et al. 1993; Hutson et al. 1998). These enzymes include malic enzyme and phosphoenolpyruvate carboxykinase. There is some controversy about whether neurons also express malic enzyme (Vogel et al. 1998; McKenna et al. 2000). Synthesis of new citric acid cycle intermediates from bicarbonate and pyruvate is accomplished by the mitochondrial enzyme pyruvate carboxylase, exclusively expressed in astrocytes in adult brain (Shank et al. 1985; Patel 1989). Together, these astrocytic anaplerotic (pyruvate carboxylase) and counteranaplerotic enzymes (e.g. malic enzyme) constitute a pyruvate/malate cycle in the brain, also referred to as pyruvate cycling (Cerdan et al. 1990; Cruz et al. 1998). Studies described in this paper were designed to estimate fluxes through the pyruvate/malate cycle.

Because of the high degree of compartmentalization of the cycle and the complexity of the brain, it has been difficult to understand how the pyruvate/malate cycle is regulated and whether it is capable of influencing neurotransmission or neurodegeneration due to excess glutamate. In the present study, we have conducted a full kinetic analysis using methods involving both ${ }^{14} \mathrm{C}$ (entry of label via anaplerosis in astrocytes) and ${ }^{13} \mathrm{C}$ (entry of label via glucose in neurons) to get an accurate value for brain glutamate turnover in vivo in awake animals. In awake rats, the present study demonstrates that anaplerosis provides a substantial fraction of the glutamine synthesized in the astrocytes. We further used this approach to test whether acute administration of gabapentin inhibits global brain de novo glutamate synthesis in vivo. Gabapentin is a neuroactive drug used clinically to treat epilepsy (Bergey et al. 1997) and chronic pain (Rowbotham et al. 1998), and we have shown that this leucine analog inhibits de novo (anaplerotic) glutamate synthesis from $\mathrm{H}^{14} \mathrm{CO}_{3}^{-}$in rat retinas (Hutson et al. 2001; LaNoue et al. 2001; Lieth et al. 2001).

\section{Materials and methods}

\section{Experimental animals}

Male Sprague-Dawley rats $(244 \pm 18$ g, Harlan, Madison, WI, USA) were used for whole animal in vivo perfusions. The perfusions were done at Wake Forest University School of Medicine. These rats were housed under a 12-h light/dark cycle and allowed free access to food and water. After surgery, a liquid diet was provided (Bio-Serv, Frenchtown, NJ, USA; product no. F1259SP) instead of the standard chow diet. The study protocol was approved by the Institutional Review Committee (IRC) of the Wake Forest University School of Medicine. Animals were treated in accordance with the guidelines published in the NIH Guide for the Care and Use of Laboratory Animals. Sprague-Dawley rats were used as a source of excised retinas for ex vivo studies. The rats were exposed to a 12-h light/dark cycle and had free access to food and water. The ex vivo retinal 
study protocol, which was carried out at Penn State, was approved by the IRC at the Penn State University College of Medicine.

\section{Chemicals}

The neuroactive drug gabapentin (neurontin) was a gift from ParkeDavis Pharmaceutical Research Division of Warner-Lambert Co., (Ann Arbor, MI, USA). Radioactive sodium ${ }^{14} \mathrm{C}$-bicarbonate (NEC086H) was purchased from NEN Life Science Products, Inc. (Boston, MA, USA). D- $\left[1-{ }^{13} \mathrm{C}\right]$ glucose was purchased from Cambridge Isotope (CLM-420; Andover, MA, USA). Enzymes for metabolic analyses were purchased from Sigma Aldrich or Roche Molecular Biochemicals (Indianapolis, IN, USA).

\section{Experimental procedure for in vivo brain studies}

For in vivo studies, rats were anesthetized with intraperitoneal (i.p.) Nembutal ( $75 \mathrm{mg} / \mathrm{kg}$ body weight) and sterile surgery performed to implant catheters in the carotid artery and jugular vein as described by Crist et al. (1998). The animals were allowed to recover from surgery for 48-72 $\mathrm{h}$ and had free access to a liquid diet. On the day of the experiment rats were placed in a metabolic cage with an air flow inlet and outlet. The outlet air was passed through a column of $\mathrm{NaOH}$ pellets to trap ${ }^{14} \mathrm{CO}_{2}{ }^{-}$. The metabolic cage was located within a fume hood. The catheters emerged from the rats attached to a swivel apparatus at the back of the rats' necks. Isotopes were infused through the venous catheter and blood samples taken from the carotid artery catheter. Gabapentin $(100 \mathrm{mg} / \mathrm{kg})$ or saline was administered i.p. $30 \mathrm{~min}$ prior to the start of the glucose and bicarbonate infusion. The infusion medium consisted of $1 \mathrm{mCi}$ sodium ${ }^{14} \mathrm{C}$-bicarbonate, 1 mmole $100 \%$ enriched $\left[1-{ }^{13} \mathrm{C}\right]$ glucose, and $0.1 \mathrm{mmole} \mathrm{NaCl}$ per $\mathrm{ml}$ sterile $\mathrm{H}_{2} \mathrm{O}$. A priming dose of the infusion medium $(0.5 \mathrm{~mL})$ was followed immediately by a steady infusion $(1 \mathrm{~mL} / \mathrm{h})$ lasting from 5 to 60 min. During the infusion, blood samples were taken from the carotid artery at 5, 10, 20, 40, and $60 \mathrm{~min}$ after the priming dose. Acid volatile $\left(\mathrm{H}^{14} \mathrm{CO}_{3}{ }^{-}\right)$radioactivity in the blood was determined as well as glucose ${ }^{13} \mathrm{C}$ fractional enrichment in these blood samples. Serum $\mathrm{pH}, \mathrm{HCO}_{3}{ }^{-}$, and $\mathrm{pCO}_{2}$ was measured in parallel experiments to estimate venous $\mathrm{HCO}_{3}{ }^{-}$specific activity. Incorporation of ${ }^{14} \mathrm{C}$ from $\mathrm{H}^{14} \mathrm{CO}_{3}{ }^{-}$into serum glucose due to hepatic gluconeogenesis was assessed to be small, because these fed rats exhibit low rates of hepatic gluconeogenesis. The average specific radioactivity of serum glucose was $\sim 10 \mathrm{dpm} / \mathrm{nmol}$ compared to a value of $113 \pm 4 \mathrm{dpm} /$ nmol for serum $\mathrm{H}^{14} \mathrm{CO}_{3}^{-}$. The blood glucose concentration varied from 5 to $8 \mathrm{~mm}$.

The priming dose and continuous infusion of $\mathrm{H}^{14} \mathrm{CO}_{3}{ }^{-}$into the jugular vein kept the specific activity of $\mathrm{H}^{14} \mathrm{CO}_{3}{ }^{-}$constant with time in individual rats, though the value varied among animals. Infusion of $\left[1-{ }^{13} \mathrm{C}\right]$ glucose resulted in an average isotopic ${ }^{13} \mathrm{C}$-enrichment for serum glucose of $0.541 \pm 0.013, n=31$. The injection of gabapentin into the experimental animals prior to the steady-state infusions did not change this ${ }^{13} \mathrm{C}$ enrichment value significantly.

At the end of the infusion, the rats were decapitated and their heads dropped immediately into liquid nitrogen. The frozen brain tissue was removed from the skull, and the cerebellum was separated from the other brain tissue. The tissue (whole brain minus cerebellum) was then extracted with $6 \%$ perchloric acid and neutralized with $\mathrm{KOH}$. Enzymatic assays of glucose, lactate, $\alpha$-ketoglutarate, glutamate, and glutamine were performed by standard procedures (Bergmeyer 1965; Williamson and Corkey
1969), and ion exchange chromatography (Gamberino et al. 1997) was used to separate metabolites. On average, each extract contained about $950 \mathrm{mg}$ wet weight of tissue and $70 \mathrm{mg}$ protein, which amounts to a $7.5 \%$ protein content of the wet brain.

The data are presented as nmoles of metabolite/mg protein. The time averaged serum $\mathrm{H}^{14} \mathrm{CO}_{3}^{-}$specific radioactivity, separately determined for each animal, was used to calculate the nmoles of $\mathrm{H}^{14} \mathrm{CO}_{3}^{-}$incorporated into each brain metabolite, reported as nmoles $\mathrm{H}^{14} \mathrm{CO}_{3}^{-}$incorporated/mg protein. Protein was determined by the Bradford (1976) procedure after diluting and solubilizing the perchloric acid brain extract protein pellet with $1 \mathrm{M} \mathrm{NaOH}$.

\section{Experimental procedure for ex vivo retinal studies}

Retinas were surgically removed from anesthetized rats as described previously (Lieth et al. 2001). Half retinas minus pigment epithelium were placed immediately in $1 \mathrm{~mL}$ Krebs bicarbonate buffer containing $5 \mathrm{~mm}$ glucose, $0.2 \mathrm{~mm}$ pyruvate, and $0.03 \mathrm{~mm} \mathrm{NH}_{4} \mathrm{Cl}$. The medium was equilibrated with $5 \% \mathrm{CO}_{2}, 95 \% \mathrm{O}_{2}$ at $37^{\circ} \mathrm{C}$, $\mathrm{pH}$ 7.4. Gabapentin (1 mM) was included in one half of the incubations. After a 3-min equilibration period, $150 \mu \mathrm{Ci}$ of $\mathrm{H}^{14} \mathrm{CO}_{3}{ }^{-}$ was added, the vessels were sealed to maintain $\mathrm{H}^{14} \mathrm{CO}_{3}{ }^{-}$levels, and incubations proceeded for $20 \mathrm{~min}$. We have shown previously that $20 \mathrm{~min}$ is sufficient to allow the intermediate metabolites to come to isotopic equilibrium (Lieth et al. 2001). At $t=20 \mathrm{~min}$, retinas were removed from the radiolabeled medium and placed in fresh media identical to the first but lacking the ${ }^{14} \mathrm{C}$, resulting in a pulse-chase experiment. Samples were taken at 4 min intervals during the chase period, including $t=0$ to follow the decline of ${ }^{14} \mathrm{C}$ in glutamate, glutamine, lactate, and aspartate. At these time points, retinas were removed from the medium, rinsed, and placed in $2 \%$ perchloric acid. All samples were neutralized with $\mathrm{KOH}$. The decline of specific activity of intraretinal glutamate with time followed first-order kinetics, allowing calculations of the turnover of these metabolites as well as flux through the glutamate/glutamine cycle as described previously (Lieth et al. 2001).

\section{Chromatography and enzyme analyses}

The total radioactivity in each neutralized brain or retinal extract was determined by counting a small aliquot of each sample in a Beckman scintillation counter. For the brain extracts, aliquots containing the equivalent of $\sim 45 \mathrm{mg}$ of brain protein were placed on Dowex-1 acetate ion exchange columns, and fractions collected as described previously using a step gradient of acetic acid (Gamberino et al. 1997). Metabolite peaks were pooled and total ${ }^{14} \mathrm{C}$ determined for each metabolite (glucose, glutamine, glutamate, asparate, and lactate). Glucose was separated from glutamine in the neutral fraction by conversion to glucose-6-phosphate as described previously (Lieth et al. 2001). On average, $88 \%$ of the radioactivity in each sample was identified as specific metabolites. Previous studies (Lieth et al. 2001) indicated that the remaining counts are citric acid cycle intermediates. The remainder of the unfractionated, neutralized, protein-free brain extract was used to measure the mass amount of glutamate, glutamine, aspartate, and $\alpha$-ketoglutarate using standard techniques of spectrophotometric enzymatic analysis (Bergmeyer 1965; Williamson and Corkey 1969). In the case of retinas, half of each sample was subjected to Dowex-1 chromatography to separate the ${ }^{14} \mathrm{C}$-labeled metabolites (Gamberino et al. 1997) and the other half was used for 
enzymatic assays. No ${ }^{13} \mathrm{C}$ analyses were carried out in retinal samples.

\section{NMR analysis}

The pooled fractions of each metabolite were lyophilized. The dry samples were sent to University of Minnesota where they were reconstituted in $0.35 \mathrm{~mL}$ aqueous medium containing $99 \%$ enriched ${ }^{13} \mathrm{C}$-formate and used for ${ }^{13} \mathrm{C}$ analysis by NMR. Recovery was $85-$ $95 \%$ and the measured recovery values were used to correct final data. ${ }^{13} \mathrm{C}$ NMR spectra were acquired using a $600 \mathrm{MHz}$ Varian Unity INOVA spectrometer and a pulse-acquire sequence under fully relaxed conditions $\left(45^{\circ}\right.$ pulse angle, repetition time $\mathrm{TR}=2 \times \mathrm{T}_{1}$, based on the longest experimentally determined $\mathrm{T}_{1}$ of the resonances investigated). WALTZ-16 was used for NOE generation during the relaxation delay and for decoupling during acquisition. The concentration of ${ }^{13} \mathrm{C}$-labeled metabolites was determined by integration of peak areas corrected for NOE effects relative to a known concentration of $99 \%$ enriched ${ }^{13} \mathrm{C}$-formate included in the samples. Isotopic enrichments were determined based on enzymatically measured total tissue concentrations and by isotopomer analysis at $60 \mathrm{~min}$.

The serum glucose ${ }^{13} \mathrm{C}$ isotopic enrichments were determined by ${ }^{1} \mathrm{H}-\mathrm{NMR}$ spectroscopy at $600 \mathrm{MHz}$ based on the ${ }^{1} \mathrm{H}$ resonance bound to $\mathrm{C}-1$ of $\alpha$-glucose at $5.24 \mathrm{ppm}$. The coupling between ${ }^{13} \mathrm{C}$ and ${ }^{1} \mathrm{H}$ gives rise to a doublet peak and the isotopic enrichment can be obtained from the ratio of the integral of this doublet to the whole area of the resonance. The spectra were acquired under fully relaxed conditions after reconstituting the samples in $100 \% \mathrm{D}_{2} \mathrm{O}$.

\section{Methods for calculating rates}

The steady-state kinetic method and equations used to calculate glutamate turnover, glutamate/glutamine cycle flux, and the rate of anaplerotic synthesis of glutamate have been described previously (Lieth et al. 2001). The ${ }^{13} \mathrm{C}$ labeling of glutamate was used to calculate glutamate C-4 turnover using the following expression (1), based on the derivation reproduced in the Appendix:

$$
\frac{\mathrm{d}\left({ }^{13} \mathrm{Glu}_{4}^{\infty}-{ }^{13} \mathrm{Glu}_{4}(\mathrm{t})\right)}{\mathrm{dt}}=\mathrm{k}_{\mathrm{A}}\left({ }^{13} \mathrm{Glu}_{4}^{\infty}-{ }^{13} \mathrm{Glu}_{4}(\mathrm{t})\right)
$$

If $\mathrm{A}$ is the mass amount of glutamate (pool size), then ${ }^{13} \mathrm{Glu}_{4}^{\infty} / \mathrm{A}$ is the enrichment of the C-4 of glutamate at steady-state, ${ }^{13} \mathrm{Glu}_{4}(\mathrm{t})$ is the time course of label incorporation of the C-4 of glutamate to isotopic steady state. The symbol $\mathrm{k}_{\mathrm{A}}$ is the first-order rate constant of the approach to steady state and $t$ is the elapsed time from start of ${ }^{13} \mathrm{C}$-glucose infusion. Briefly, the first-order rate constant of glutamate synthesis from $\left[1-{ }^{13} \mathrm{C}\right]$ glucose was measured by plotting the first-order approach of the percentage ${ }^{13} \mathrm{C}$-enrichment of the $\mathrm{C}-4$ of glutamate to a steady-state value. The percentage ${ }^{13} \mathrm{C}$ enrichment was plotted as a function of time and reiterative curve fitting on all experimental points carried out to estimate the rate constant $\mathrm{k}_{\mathrm{A}}$ and the ${ }^{13} \mathrm{C}$ steady-state value $(\mathrm{C} \circ)$. The value $\mathrm{k}_{\mathrm{A}}$, multiplied by the mass of glutamate, $\mathrm{A}$, represents the calculated apparent rate of glutamate breakdown, $\mathrm{V}_{\text {out }}=\mathrm{k}_{\mathrm{A}} \mathrm{A}$, which at steady state is equal to its rate of appearance. The $\mathrm{k}_{\mathrm{A}}$ also provides an estimate of the turnover time corresponding to the half-life of any isotopic label in total brain glutamate.

To estimate the amount of $\mathrm{H}^{14} \mathrm{CO}_{3}{ }^{-}$incorporated into glutamate, the dpm of ${ }^{14} \mathrm{C}$-label in glutamate at steady state was divided by the specific activity of $\mathrm{H}^{14} \mathrm{CO}_{3}^{-}(\mathrm{dpm} / \mathrm{nmol})$ resulting in nmoles
$\mathrm{H}^{14} \mathrm{CO}_{3}{ }^{-}$in glutamate/mg protein. This value was multiplied by 2 , because in the present study it was assumed that only half of each $\mathrm{H}^{14} \mathrm{CO}_{3}{ }^{-}$incorporated into oxaloacetate by pyruvate carboxylase reaches $\alpha$-ketoglutarate (Lieth et al. 2001). Thus, the corrected amount of $\mathrm{H}^{14} \mathrm{CO}_{3}{ }^{-}$incorporated into glutamate at steady state (A*) can be used to estimate the rate of synthesis of glutamate from $\mathrm{H}^{14} \mathrm{CO}_{3}{ }^{-}$when multiplied by the glutamate turnover rate constant, i.e. by $\mathrm{k}_{\mathrm{A}}$. The rate constant $\mathrm{k}_{\mathrm{A}}$ was determined as described above. The vast majority of brain glutamate is neuronal, whereas anaplerosis occurs in glia. Therefore, glutamine labeled first by $\mathrm{H}^{14} \mathrm{CO}_{3}{ }^{-}$in astrocytes must be considered the precursor of neuronal ${ }^{14} \mathrm{C}$-glutamate via the enzyme reaction catalyzed by glutaminase (see Appendix). To estimate the rate constant, $\mathrm{k}_{\mathrm{B}}$, the turnover rate constant of glutamine, we measured the first-order approach of ${ }^{14} \mathrm{C}$ glutamine to steady state using equations similar to (1) (as done for $\left[4-{ }^{13} \mathrm{C}\right]$ glutamate above and see Results). If the turnover rate constant of glutamine, $\mathrm{k}_{\mathrm{B}}$, is assumed to reflect glutamine turnover and if $\mathrm{B}^{*}$ is the nmoles of $\mathrm{H}^{14} \mathrm{CO}_{3}{ }^{-}$incorporated into glutamine at steady state, then $\mathrm{k}_{\mathrm{B}} \mathrm{B}^{*}$ is the rate of synthesis of glutamine from $\mathrm{H}^{14} \mathrm{CO}_{3}^{-}$. Multiplying $\mathrm{k}_{\mathrm{B}}$ by the glutamine mass per $\mathrm{mg}$ brain protein (B), the product $\mathrm{k}_{\mathrm{B}} \mathrm{B}$ approximates the overall rate of glutaminase at steady state, which in this study was assumed to be equal to the rate of the glutamate/glutamine cycle. As noted above, the calculated value for glutamine flux assumes all ${ }^{14} \mathrm{CO}_{2}$ fixation occurs in astrocytes. If some ${ }^{14} \mathrm{CO}_{2}$ fixation occurs in neurons, either by exchange or by net fixation through reversible malic enzyme, then the calculated rate will be overestimated.

Rates of $\mathrm{H}^{14} \mathrm{CO}_{3}{ }^{-}$incorporation into glutamate and glutamine in excised, ex vivo rat retinas were determined as described previously (Lieth et al. 2001). Briefly, half retinas were incubated for $20 \mathrm{~min}$ at $37^{\circ} \mathrm{C}$ in Krebs Ringer bicarbonate medium containing $\mathrm{H}^{14} \mathrm{CO}_{3}{ }^{-}$ $(25 \mathrm{~mm}, 150 \mu \mathrm{Ci} / \mathrm{mL}$ ). When the retinas reached steady state with respect to the ${ }^{14} \mathrm{C}$-specific activities of glutamate and glutamine, they were transferred to fresh medium with no ${ }^{14} \mathrm{C}$. Retinas were removed from the washout medium at 4-min intervals and the first-order rate constant of glutamate washout determined. The first-order rate constant is also the turnover constant $\mathrm{k}_{\mathrm{A}}$ and can be used to calculate fluxes. In this case $\mathrm{A}^{*}$ is the steady-state ${ }^{14} \mathrm{C}$ label in glutamate observed at the end of the first incubation. $\mathrm{B}^{*}$ is the steady-state ${ }^{14} \mathrm{C}$ label in glutamine. The assumption is made that $\mathrm{k}_{\mathrm{B}} \mathrm{B}^{*}=\mathrm{k}_{\mathrm{A}} \mathrm{A}^{*}$.

\section{Statistics}

Analytic values were compared by $t$-tests. For rate constants, variation and confidence limits were assessed by regression analysis. In the case of the retinal kinetics, because each rat had four half retinas, and four time points were used for ${ }^{14} \mathrm{C}$ washout curves, a rate constant could be assigned to individual rats and then these values used to obtain means and SEM.

\section{Results}

Comparison of the rates of changes in ${ }^{14} \mathrm{C}$-specific activities and ${ }^{13} \mathrm{C}$-enrichment in whole-brain glutamate and glutamine

To calculate specific activities of ${ }^{14} \mathrm{C}$-glutamate and ${ }^{14} \mathrm{C}$ glutamine, the ${ }^{14} \mathrm{C}$ in the glutamate and glutamine chromatographic peaks (in $\mathrm{dpm} / \mathrm{mg}$ ) were divided by the 
enzymatically measured amounts of glutamate and glutamine (mass amounts in nmoles/mg protein) and this specific activity was divided by the $\mathrm{H}^{14} \mathrm{CO}_{3}{ }^{-}$-specific activity. This provides a value (nmoles $\mathrm{H}^{14} \mathrm{CO}_{3}{ }^{-}$incorporated/nmol amino acid) that is independent of assayed protein. The same was done for ${ }^{13} \mathrm{C}$-enrichments which are also independent of measured protein. Enrichment is the percentage of ${ }^{13} \mathrm{C}$ in the total carbon $\left({ }^{13} \mathrm{C},{ }^{12} \mathrm{C}\right.$, and $\left.{ }^{14} \mathrm{C}\right)$ of the amino acid. Provided that most $\mathrm{H}^{14} \mathrm{CO}_{3}^{-}$is converted to citric acid cycle intermediates in the glial compartment (the site of glutamine synthesis), the specific activity of glutamine is expected to be higher than that of glutamate. Most of the glutamate in the brain is neuronal and thus ${ }^{14} \mathrm{C}$-labeled glutamate must be synthesized mainly from ${ }^{14} \mathrm{C}$-glutamine exported from the glia. Synthesis of neuronal glutamate from glucose dilutes the ${ }^{14} \mathrm{C}$ entering the neuronal pool from ${ }^{14} \mathrm{C}$-glutamine. Indeed, the ${ }^{14} \mathrm{C}$ specific activity of glutamine was 2.3 times higher than that of glutamate at isotopic steady state (Fig. 1).

The $\left[4-{ }^{13} \mathrm{C}\right]$ glutamate in the neuronal and glial pool was the result of metabolism of the infused $\left[1-{ }^{13} \mathrm{C}\right]$ glucose and was much less diluted than the ${ }^{14} \mathrm{C}$ by the intervening citric acid cycle intermediates (Fig. 1). The rate of incorporation and the steady-state values of ${ }^{13} \mathrm{C}$-enrichment were similar for glutamate and glutamine. The steady-state enrichment was approximately 0.5 times that of ${ }^{13} \mathrm{C}$-glucose enrichment


Fig. 1 Time course of ${ }^{14} \mathrm{C}$-specific activity and ${ }^{13} \mathrm{C}$ enrichment of brain glutamine and glutamate. Awake rats were perfused intravenously simultaneously with $\mathrm{H}^{14} \mathrm{CO}_{3}{ }^{-}$and $\left[1-{ }^{13} \mathrm{C}\right]$ glucose. Some rats (c and d) were injected intraperitoneally with $100 \mathrm{mg} / \mathrm{kg}$ gabapentin prior to the start of perfusion. Times shown are elapsed time after start of isotope infusion. Glutamate $(\mathbf{\Lambda})$ and glutamine $(\bullet)$ were isolated from neutralized perchloric extracts of brain tissue. (a) and (c) provide values for ${ }^{14} \mathrm{C}$-specific activity, and (b) and (d), ${ }^{13} \mathrm{C}$ enrichment of glutamate and glutamine. Values shown are means \pm SEM. as only half the pyruvate reaching brain mitochondria is labeled by the $\left[1-{ }^{13} \mathrm{C}\right]$ glucose.

Gabapentin did not lower rates of incorporation of ${ }^{14} \mathrm{C}$ or ${ }^{13} \mathrm{C}$ into glutamate or glutamine (Fig. 1).

\section{Turnover of brain glutamate}

To determine the first-order rate constant of glutamate turnover we analyzed the kinetics of the approach of $\left[4-{ }^{13} \mathrm{C}\right]$ glutamate to steady state. We assumed that the $\left[4-{ }^{13} \mathrm{C}\right]$ glutamate signal was dominated by a single neuronal glutamate pool which approached a steady value of ${ }^{13} \mathrm{C}$ enrichment as a first-order function. Fitting the solution of (1) (see Methods) to the experimental data provided a good fit with $\mathrm{k}_{\mathrm{A}}$ equal to $0.066 / \mathrm{min}$ (Fig. 2). Individual data points were used for the curve fitting, but only means and standard errors of the means are shown in Fig. 2. Judging from the glutamate concentration (A) and the turnover rate constant $\left(\mathrm{k}_{\mathrm{A}}=0.066 / \mathrm{min}\right)$, the turnover of glutamate $\left(\mathrm{k}_{\mathrm{A}} \mathrm{A}=\right.$ $9.4 \pm 0.7 \mathrm{nmoles} / \mathrm{min} / \mathrm{mg}$ protein) was not altered statistically due to the presence of gabapentin (Table 1).

Knowing the first-order rate constant of glutamate turnover, it is also possible to calculate the rate of synthesis of glutamate from $\mathrm{H}^{14} \mathrm{CO}_{3}{ }^{-}$. The first-order rate constant applies to the whole glutamate pool and any isotopic fraction of that pool. $\mathrm{A}^{*}$ is the nmoles of $\mathrm{H}^{14} \mathrm{CO}_{3}{ }^{-}$incorporated into the total glutamate pool per $\mathrm{mg}$ of protein at steady state. Multiplying steady-state ${ }^{14} \mathrm{C}$-glutamate specific activity (Fig. 1) by the mass of glutamate per $\mathrm{mg}$ of protein, provides the value for $\mathrm{A}^{*}=10.60 \pm 0.05$ nmoles $\mathrm{H}^{14} \mathrm{CO}_{3}{ }^{-} / \mathrm{mg}$ of protein in the glutamate pool. The calculated rate of synthesis is equal to $2 \times \mathrm{k}_{\mathrm{A}} \mathrm{A}^{*}=1.4 \pm 0.1$ nmoles $\mathrm{H}^{14} \mathrm{CO}_{3}{ }^{-} / \mathrm{min} / \mathrm{mg}$ protein, which is $\sim 15 \%$ of the turnover of glutamate.

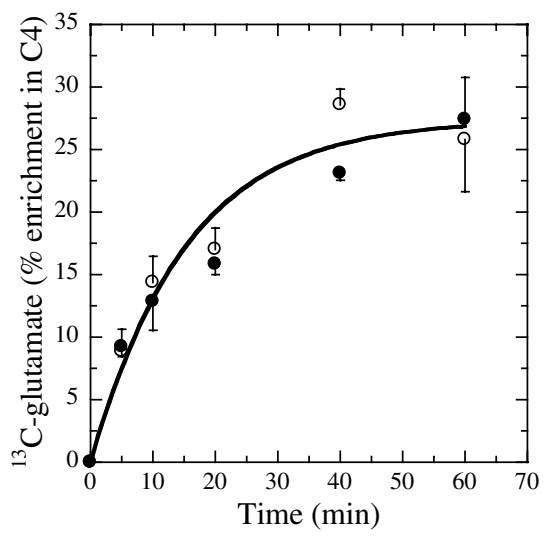

Fig. 2 Time course of ${ }^{13} \mathrm{C}$ enrichment of brain glutamate in the presence and absence of gabapentin. Conditions are identical to those described in Fig. 1. The data points (means \pm SEM) are shown in open (control) or closed circles (gabapentin). The line drawn represents the theoretical equation for first-order approach to a steady-state value of percentage $\left[4-{ }^{13} \mathrm{C}\right]$ glutamate enrichment equal to $27 \%$ and a rate constant $\left(\mathrm{k}_{\mathrm{A}}\right)$ equal to $0.066 / \mathrm{min}$. 
Table 1 Rate parameters of glutamate metabolism in whole brain in vivo

\begin{tabular}{|c|c|c|c|}
\hline Parameter & Control & Gabapentin & Description \\
\hline $\mathrm{k}_{\mathrm{A}}(/ \mathrm{min})\left[4-{ }^{13} \mathrm{C}\right]$ glutamate & $0.066 \pm 0.005$ & $0.066 \pm 0.005$ & First-order rate constant of $\left[4-{ }^{13} \mathrm{C}\right]$ glutamate turnover \\
\hline $\mathrm{k}_{\mathrm{B}}(/ \mathrm{min}){ }^{14} \mathrm{C}$-glutamine & $0.084 \pm 0.010$ & $0.084 \pm 0.010$ & First-order rate constant of $\left[1-{ }^{14} \mathrm{C}\right]$ glutamine turnover \\
\hline $\mathrm{A}^{*}{ }^{14} \mathrm{C}$-glutamate (nmoles $\mathrm{H}^{14} \mathrm{CO}_{3}{ }^{-} / \mathrm{mg}$ protein) & $9.79 \pm 0.47$ & $9.06 \pm 0.40$ & Steady-state value of glutamate labeled with $\mathrm{H}^{14} \mathrm{CO}_{3}{ }^{-}$ \\
\hline $\mathrm{B}^{*}{ }^{14} \mathrm{C}$-glutamine (nmoles $\mathrm{H}^{14} \mathrm{CO}_{3}{ }^{-} / \mathrm{mg}$ protein) & $8.80 \pm 0.06$ & $8.30 \pm 0.30$ & Steady-state value of glutamine labeled with $\mathrm{H}^{14} \mathrm{CO}_{3}{ }^{-}$ \\
\hline A glutamate mass (nmoles/mg protein) & $142.2 \pm 2.5$ & $140.4 \pm 2.1$ & Glutamate/mg protein \\
\hline B glutamine mass (nmoles/mg protein) & $54.9 \pm 2.0$ & $51.6 \pm 1.3$ & Glutamine/mg protein \\
\hline $\mathrm{k}_{\mathrm{A}}\left(\mathrm{A}^{*}\right) \times 2\left(\mathrm{nmoles} \mathrm{H}^{14} \mathrm{CO}_{3}{ }^{-} / \mathrm{min} / \mathrm{mg}\right.$ protein $)$ & $1.29 \pm 0.11$ & $1.20 \pm 0.10$ & Flux of radiolabeled carbon into and out of glutamate \\
\hline $\mathrm{k}_{\mathrm{B}}\left(\mathrm{B}^{*}\right) \times 2\left(\mathrm{nmoles} \mathrm{H}^{14} \mathrm{CO}_{3}{ }^{-} / \mathrm{min} / \mathrm{mg}\right.$ protein $)$ & $1.48 \pm 0.17$ & $1.39 \pm 0.17$ & Flux of radiolabeled carbon into and out of glutamine \\
\hline $\mathrm{k}_{\mathrm{A}} \mathrm{A}$ (nmoles/min/mg protein) & $9.39 \pm 0.73$ & $9.27 \pm 0.72$ & Turnover of total glutamate in the brain \\
\hline $\mathrm{k}_{\mathrm{B}} \mathrm{B}$ (nmoles $/ \mathrm{min} / \mathrm{mg}$ protein) & $4.61 \pm 0.57$ & $4.33 \pm 0.53$ & Glutamate/glutamine cycle flux \\
\hline
\end{tabular}

Therefore the percentage of the total glutamate pool provided by the anaplerotic pathway is $\sim 15 \%$.

\section{Turnover of brain glutamine}

The first-order rate constant of glutamine turnover $\left(\mathrm{k}_{\mathrm{B}}\right)$ and the steady-state value of ${ }^{14} \mathrm{C}$-glutamine $\left(\mathrm{B}^{*}\right.$, the nmoles $\mathrm{H}^{14} \mathrm{CO}_{3}^{-} / \mathrm{mg}$ protein in glutamine) were estimated from changes in ${ }^{14} \mathrm{C}$-glutamine (Fig. 3). Reiterative trials of (1) matching the changes of ${ }^{14} \mathrm{C}$-glutamine with time, using $0.084 / \mathrm{min}$ as the first-order rate constant provides the best match of the data to the theoretical curve (Fig. 3). To obtain the rate of disappearance of ${ }^{14} \mathrm{C}$-glutamine in control rats, $\mathrm{k}_{\mathrm{B}}$ was multiplied by the steady-state value of ${ }^{14} \mathrm{C}$-glutamine $\left(\mathrm{B}^{*}=8.80 \pm 0.06 \mathrm{nmoles} / \mathrm{min} / \mathrm{mg}\right)$ and by 2 , resulting in $2 \mathrm{k}_{\mathrm{B}} \mathrm{B}^{*}=1.48 \pm 0.17 \mathrm{nmoles} / \mathrm{min} / \mathrm{mg}$ protein. The rate of synthesis of radiolabeled glutamate, $2 \mathrm{k}_{\mathrm{A}} \mathrm{A}^{*}$ (Fig. 2) was $1.29 \pm 0.11 \mathrm{nmoles} / \mathrm{min} / \mathrm{mg}$ protein. The observation that ${ }^{14} \mathrm{C}$-glutamate synthesis is slightly lower than glutamine



Fig. 3 The time course of changes in $\mathrm{H}^{14} \mathrm{CO}_{3}{ }^{-}$incorporated into brain glutamine (nmoles $/ \mathrm{mg}$ ) of control and gabapentin-treated rats. Conditions are identical to those described in Fig. 1. Data points (means \pm SEM) are shown as control $(\bigcirc)$ or gabapentin $(\bullet)$. The line drawn represents the theoretical equation for first-order approach to a steady-state value. Values shown are nmoles ${ }^{14} \mathrm{CO}_{2}$ incorporated into glutamine/mg protein. breakdown is consistent with the possibility that some ${ }^{14} \mathrm{C}$ glutamine is lost from the glial compartment and may exit the brain. The fact that ${ }^{14} \mathrm{C}$-glutamine synthesis only slightly exceeded ${ }^{14} \mathrm{C}$-glutamate synthesis suggests that little anaplerosis takes place in neurons.

The glutamate/glutamine cycle flux in the present study (assessed as total glutamine turnover) was $4.6 \pm 0.6$ nmoles/ $\mathrm{min} / \mathrm{mg}$ protein for the control rats and $4.3 \pm 0.5$ nmoles/ $\mathrm{min} / \mathrm{mg}$ protein for the gabapentin-treated rats (Table 1). Dividing the glutamate/glutamine cycle flux by total glutamate turnover, $\mathrm{k}_{\mathrm{A}} \mathrm{A}$, provided an estimate of the fraction of total glutamate metabolism that was used for neurotransmission, which was $\mathrm{k}_{\mathrm{B}} \mathrm{B} / \mathrm{k}_{\mathrm{A}} \mathrm{A}=0.49$ (see Table 1 ).

\section{Effect of gabapentin on glutamate metabolism in the retina}

The conclusion that gabapentin is without effect on the rate constant for glutamate turnover, the steady-state specific radioactivity of glutamine and glutamate, and the calculated rate of incorporation of $\mathrm{H}^{14} \mathrm{CO}_{3}^{-}$was surprising in view of previous results that showed gabapentin reduces the steadystate ${ }^{14} \mathrm{C}$-labeling of the glutamine and glutamate pool in $e x$ vivo rat retinas (Hutson et al. 2001; LaNoue et al. 2001; Lieth et al. 2001). In these studies the first-order rate constant for glutamate turnover was not determined in the presence of added gabapentin. Therefore, to determine whether acute treatment of excised rat retinas with gabapentin influences the turnover rate of retinal glutamate, we carried out kinetic analysis of $\left[1-{ }^{14} \mathrm{C}\right]$ glutamate disappearance during the chase phase of a $\mathrm{H}^{14} \mathrm{CO}_{3}{ }^{-}$pulse/chase experiment. The natural log of intraretinal $\left[1-{ }^{14} \mathrm{C}\right]$ glutamate/ $\mathrm{mg}$ was plotted as a function of time (Fig. 4), based on mathematical expressions analogous to (1). Calculated values of $\mathrm{k}_{\mathrm{A}}$ for glutamate turnover were $0.097 \pm 0.004 / \mathrm{min}$ for control conditions and $0.096 \pm 0.005 / \mathrm{min}$ for incubations with $1 \mathrm{~mm}$ gabapentin (Table 2).

Although the first-order rate constants of glutamate turnover were similar, the results confirmed that the steadystate amounts of $\mathrm{H}^{14} \mathrm{CO}_{3}{ }^{-}$incorporated into both glutamate 


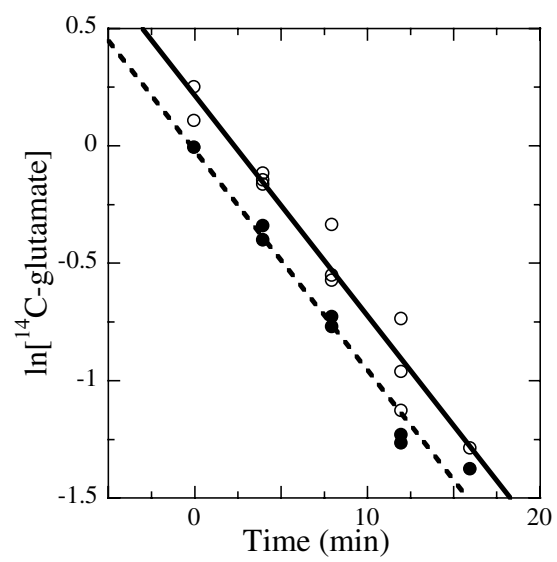

Fig. 4 The effect of gabapentin in the excised rat retina on the washout of ${ }^{14} \mathrm{C}$ from intraretinal ${ }^{14} \mathrm{C}$-glutamate (nmoles ${ }^{14} \mathrm{C}$-glutamate/ $\mathrm{mg}$ protein). Experimental conditions are described in Methods. ${ }^{14} \mathrm{C}$-glutamate values were transformed to natural log in order to linearize the data. Data collected in control retinas $(\bigcirc)$ and data collected in the presence of $1 \mathrm{~mm}$ gabapentin (0). The slope of the line $(\ln / \Delta t)$ is equal to $k_{A}$. Values shown are means of individual data points where $n=8$.

and glutamine and the mass amounts of glutamine were reduced by gabapentin. The ${ }^{14} \mathrm{C}$ label in glutamate was $14 \%$ lower $(p<0.022)$ due to gabapentin and 38\% lower in glutamine ( $p<0.005$; Figs $5 \mathrm{a}$ and $\mathrm{b}$ and Table 2$)$. The $23 \%$ decrease in the mass of glutamine due to gabapentin is shown in Fig. 5(d). Using the data illustrated in Figs 4 and 5 and applying steady-state analyses described in Methods [e.g. equations similar to (1) and in Lieth et al. 2001], glutamate fluxes with and without gabapentin were calculated (Table 2). The de novo synthesis of ${ }^{14} \mathrm{C}$-glutamate was decreased by $16 \%$ in the presence of gabapentin. The fraction of glutamate disappearance that is due to neurotransmission was 0.37 , thus lower than the fraction used for neurotransmission in the awake brain. Previous estimates (LaNoue et al. 2001; Lieth et al. 2001) of the decline in de novo synthesis of glutamate and glutamine were based on the steady-state ${ }^{14} \mathrm{C}$ content of glutamate plus glutamine, which were consistently found to be $\sim 30 \%$ lower in the presence of $1 \mathrm{~mm}$ gabapentin. In this study, the same type of estimation provides a value of $22 \%$.

\section{Discussion}

The work described here was intended to provide a new perspective with which to examine glutamate metabolism in the awake, in vivo, mammalian brain. We reported a preliminary study previously (Lieth et al. 2001) with conclusions similar to those reported here. That study showed $\mathrm{H}^{14} \mathrm{CO}_{3}{ }^{-}$incorporation into glutamate at a single time point only, so a kinetic analysis was not possible. By collecting data at five time points and perfusing awake rats simultaneously with $\left[1-{ }^{13} \mathrm{C}\right]$ glucose and $\mathrm{H}^{14} \mathrm{CO}_{3}{ }^{-}$, it is possible now to measure kinetic parameters and absolute fluxes. Thus, in this study of glucose and glutamate metabolism in the brain, we measured ${ }^{14} \mathrm{C}$ at different time points and also analyzed incorporation of ${ }^{13} \mathrm{C}$ into key metabolites. ${ }^{13} \mathrm{C}$ NMR has the unique ability to noninvasively track labeled carbon and labeled nitrogen as they pass through different metabolites and sequentially label different atoms within the same molecule. Disadvantages include lack of sensitivity and the complexity of the information provided that must be deconvoluted by assumption of specific models and by use of computer programs to obtain clear cut values for metabolic fluxes.

${ }^{13} \mathrm{C}$ NMR was first applied to the study of brain metabolism in the 1980s and early 1990 s by several groups (Morris et al. 1985; Badar-Goffer et al. 1990; Cerdan et al. 1990; Fitzpatrick et al. 1990), but recently these studies have gained increased attention because of the successful application of NMR techniques for the measurement of global glutamatergic action in vivo (Aureli et al. 1997; Lapidot and Gopher 1997; Sibson et al. 1997, 1998; Gruetter et al. 1998; Merle et al. 2002). Conclusions drawn by these studies, however, have not been universally accepted. One issue has been the relationship

Table 2 Rate parameters of glutamate metabolism in excised rat retinas

\begin{tabular}{|c|c|c|c|}
\hline Parameter & Control & Gabapentin & Description \\
\hline $\mathrm{k}_{\mathrm{A}}(/ \mathrm{min}){ }^{14} \mathrm{C}$-glutamate & $0.097 \pm 0.004$ & $0.096 \pm 0.005$ & First-order rate constant of $\left[1-{ }^{14} \mathrm{C}\right]$ glutamate turnover \\
\hline $\mathrm{k}_{\mathrm{B}}(/ \mathrm{min}){ }^{14} \mathrm{C}$-glutamine & $0.233 \pm 0.021$ & $0.319 \pm 0.027$ & First-order rate constant of $\left[1-{ }^{14} \mathrm{C}\right]$ glutamine turnover \\
\hline $\mathrm{A}^{*}{ }^{14} \mathrm{C}$-glutamate (nmoles $\mathrm{H}^{14} \mathrm{CO}_{3}^{-} / \mathrm{mg}$ protein) & $1.19 \pm 0.05$ & $1.02 \pm 0.03$ & Steady-state value of glutamate labeled with $\mathrm{H}^{14} \mathrm{CO}_{3}^{-}$ \\
\hline $\mathrm{B}^{\star 14} \mathrm{C}$-glutamine (nmoles $\mathrm{H}^{14} \mathrm{CO}_{3}^{-} / \mathrm{mg}$ protein) & $0.511 \pm 0.033$ & $0.315 \pm 0.016$ & Steady-state value of glutamine labeled with $\mathrm{H}^{14} \mathrm{CO}_{3}^{-}$ \\
\hline A glutamate mass (nmoles/mg protein) & $49.84 \pm 1.24$ & $52.55 \pm 1.07$ & Glutamate/mg protein \\
\hline B glutamine mass (nmoles/mg protein) & $7.61 \pm 0.31$ & $5.86 \pm 0.19$ & Glutamine/mg protein \\
\hline $\mathrm{k}_{\mathrm{A}}\left(\mathrm{A}^{*}\right) \times 2\left(\right.$ nmoles $\mathrm{H}^{14} \mathrm{CO}_{3}^{-} / \mathrm{min} / \mathrm{mg}$ protein $)$ & $0.232 \pm 0.012$ & $0.196 \pm 0.012$ & Flux of radiolabeled carbon into and out of glutamate \\
\hline $\mathrm{k}_{\mathrm{B}}\left(\mathrm{B}^{\star}\right) \times 2\left(\right.$ nmoles $\mathrm{H}^{14} \mathrm{CO}_{3}{ }^{-} / \mathrm{min} / \mathrm{mg}$ protein $)$ & $0.232 \pm 0.012$ & $0.196 \pm 0.012$ & Flux of radiolabeled carbon into and out of glutamine \\
\hline $\mathrm{k}_{\mathrm{A}} \mathrm{A}$ (nmoles $\mathrm{H}^{14} \mathrm{CO}_{3}{ }^{-} / \mathrm{min} / \mathrm{mg}$ protein) & $4.83 \pm 0.23$ & $5.04 \pm 0.28$ & Turnover of total glutamate in the retina \\
\hline $\mathrm{k}_{\mathrm{B}} \mathrm{B}$ (nmoles $\mathrm{H}^{14} \mathrm{CO}_{3}^{-} / \mathrm{min} / \mathrm{mg}$ protein) & $1.77 \pm 0.18$ & $1.87 \pm 0.17$ & Glutamate/glutamine cycle flux \\
\hline
\end{tabular}



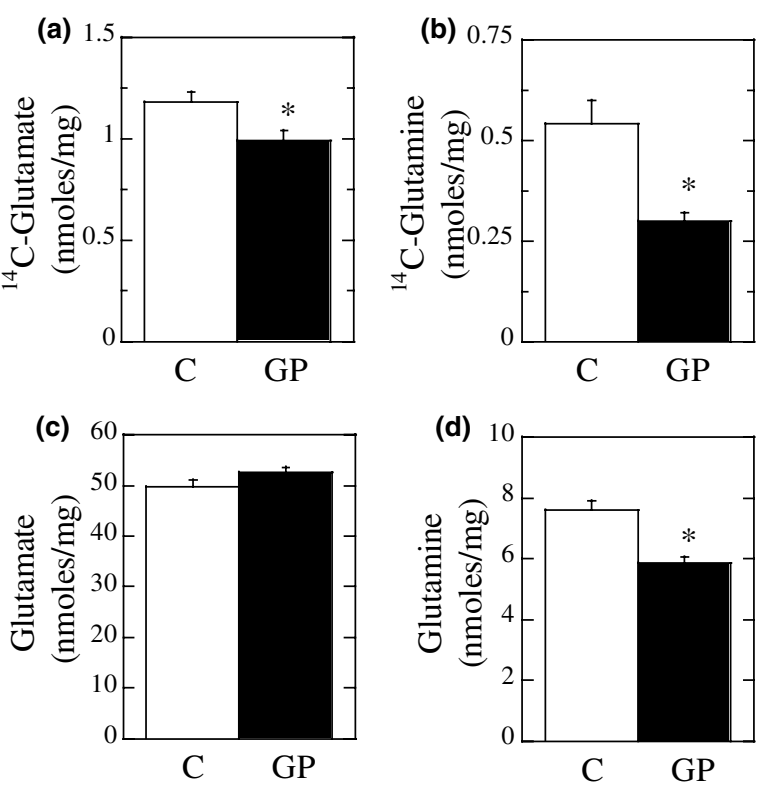

Fig. 5 Effect of gabapentin on incorporation of $\mathrm{H}^{14} \mathrm{CO}_{3}{ }^{-}$into glutamate and glutamine in the retina at steady-state and their mass amounts. Values shown are steady-state levels of ${ }^{14} \mathrm{C}$-glutamate (a) and ${ }^{14} \mathrm{C}$-glutamine (b) after a $20 \mathrm{~min}$ ex vivo incubation of excised retinas with $25 \mathrm{mM} \mathrm{H}^{14} \mathrm{CO}_{3}{ }^{-}$prior to washout. Values are means \pm SEM, $n=8$. The $p$-value for ${ }^{14} \mathrm{C}$-glutamate is 0.022 and the $p$-value for ${ }^{14} \mathrm{C}$-glutamine is 0.005 . The mass ( $\mathrm{nmoles} / \mathrm{mg}$ protein) of unlabeled glutamate (c) and glutamine (d) remained constant during the washout phase of the experiment. Therefore values taken during the entire time course were used to obtain the data shown. Values are means \pm SEM, $n=32$. The $p$-value for glutamine mass is 0.005 . Control retinas $(\square)$ and retinas incubated with $1 \mathrm{~mm}$ gabapentin (ם).

between flux through the glutamine/glutamine cycle and glucose utilization. Another has been the magnitude and relative importance of the synthesis of glutamate de novo from $\mathrm{CO}_{2}$ and pyruvate, which has been addressed in the present study.

The measurement of anaplerotic fluxes from pyruvate and $\mathrm{CO}_{2}$ to glutamine is difficult to assess with ${ }^{13} \mathrm{C}$-glucose and values vary widely from $1 \%$ to $35 \%$ of total glutamine synthesis (Shank et al. 1993; Aureli et al. 1997; Lapidot and Gopher 1997; Sibson et al. 1997; Gruetter et al. 1998, 2001). Some elegant studies have assessed glial metabolism, where anaplerosis takes place, by using the glial-specific tracer, ${ }^{13} \mathrm{C}$ acetate (Bluml et al. 2002; Lebon et al. 2002) and these resulted in an estimate of glial citric acid cycle consistent with earlier human studies (Gruetter et al. 2001). In the modeling employed by Lebon et al. (2002), an upper limit for anaplerotic synthesis of glutamate, relative to the glutamate/glutamine cycle of $\sim 30 \%$ in human brain was estimated. The data obtained in the Lebon study did not permit a direct, absolute estimate of anaplerosis but rather provided a value for the glial citric acid cycle flux that included anaplerosis.
Another method used for estimating anaplerosis involved the measurement of the difference between $\left[2-{ }^{13} \mathrm{C}\right]$ and $\left[3-{ }^{13} \mathrm{C}\right]$ isotopic enrichment in glutamine when $\left[1-{ }^{13} \mathrm{C}\right]$ glucose was the substrate. This model made the assumption that there is little or no equilibration between oxaloacetate (the initial product of pyruvate carboxylase) and symmetrical fumarate. Complete equilibration would equalize $\left[2-{ }^{13} \mathrm{C}\right]$ and $\left[3-{ }^{13} \mathrm{C}\right]$ of glutamine making an estimate impossible. If equilibration occurs but is incomplete, estimation of anaplerosis provides a lower limit. Some other studies use models that provide a value for the ratio of PDH flux to glial pyruvate carboxylase - but do not estimate absolute values (Lapidot and Gopher 1997; Griffin et al. 2003).

The classical way to measure anaplerosis involves use of radioisotopes $\left(\mathrm{H}^{14} \mathrm{CO}_{3}^{-}\right.$or $\left[1-{ }^{14} \mathrm{C}\right]$ pyruvate $)$ as substrates (Heath and Rose 1985). The $\mathrm{H}^{14} \mathrm{CO}_{3}{ }^{-}$subsequently labels the $\mathrm{C}-1$ of $\alpha$-ketoglutarate and hence only the $\mathrm{C}-1$ in glutamate and glutamine (see Figure 6). This label is lost as ${ }^{14} \mathrm{CO}_{2}$ when $\alpha$-ketoglutarate is oxidized to succinate and, thus, the amino acids glutamate and glutamine remain labeled only at the $\mathrm{C}-1$ position. This simplifies the analysis once the amino acids are separated chromatographically. In fact, brain anaplerosis was estimated over 40 years ago by infusing $\mathrm{H}^{14} \mathrm{CO}_{3}^{-}$into cats and measuring ${ }^{14} \mathrm{C}$ in glutamate, glutamine and aspartate, subsequently isolated from the frozen brain tissue (Berl et al. 1962; Waelsch et al. 1964). Although absolute rates were not directly reported, the present data are in good agreement with these early studies, as judged by a comparison of our $\mathrm{H}^{14} \mathrm{CO}_{3}{ }^{-}$incorporation into glutamate and glutamine with theirs, at similar time points.

In order to measure anaplerosis directly we have used the 40 years old Waelsch et al. (1964) method, of perfusing awake animals with $\mathrm{H}^{14} \mathrm{CO}_{3}^{-}$and separating metabolites chromatographically to determine ${ }^{14} \mathrm{C}$ incorporation. Incorporation of $\mathrm{H}^{14} \mathrm{CO}_{3}^{-}$into glutamate and glutamine was measured by multiplying the first-order rate constants of amino acid turnover in these pools by the steady-state values of $\mathrm{H}^{14} \mathrm{CO}_{3}^{-}$incorporated. The glutamate rate constant was determined from the ${ }^{13} \mathrm{C}$ entry kinetics. The glutamine rate constant was derived directly from the ${ }^{14} \mathrm{C}$ entry kinetics. The method assumes that intervening metabolites (e.g. between glucose and glutamate and between $\mathrm{H}^{14} \mathrm{CO}_{3}^{-}$and glutamine) reach steady state quickly. The fluxes calculated in this way agree with some previous publications that have employed ${ }^{13} \mathrm{C}$-glucose alone as substrate precursor (Gruetter et al. 2001). It was also possible to use the data to calculate flux through the glutamate/glutamine cycle. Our data indicate that about $50 \%$ of total glutamate turnover is used for neurotransmission. This assumes that glutamate/glutamine cycle flux provides a measure of glutamatergic neurotransmission.

The values we generate agree with the raw data of some recent papers that use ${ }^{13} \mathrm{C} \mathrm{NMR}$ to evaluate glutamate 


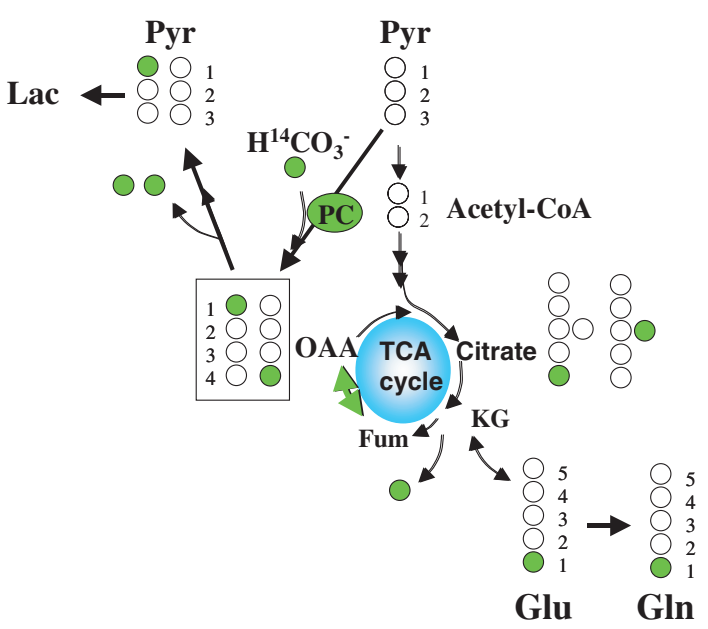

Fig. 6 Astrocyte ${ }^{14} \mathrm{C}$-labeling pattern from $\mathrm{H}^{14} \mathrm{CO}_{3}{ }^{-}$. Label enters the TCA cycle via pyruvate carboxylase (PC) and label equilibrates between oxaloacetate (OAA) and fumarate (Fum). Decarboxylation of OAA by malic enzyme or phosphoenolpyruvate carboxykinase produces pyruvate labeled in the 1 position only if there is equilibration between OAA and Fum.

metabolism and its relationship to glucose consumption (Sibson et al. 1998). The conclusion of those papers was that glutamine/glutamate cycle flux is approximately equimolar to brain glucose consumption over a range of glutamatergic activity. The precise relationship mentioned is: glucose consumption $=1.04$ (glutamate/glutamine cycle flux $)+0.1$. The assumptions made in drawing this conclusion were that citric acid cycle flux is twice the rate of glucose consumption, that citric acid cycle flux is equivalent to flux through $\alpha$-ketoglutarate dehydrogenase, and that mitchondrial $\alpha$-ketoglutarate is in isotopic equilibrium with cytosolic glutamate. Our raw data agree with the data of these workers but, like some others (Yu et al. 1995; O'Donnell et al. 1998; Griffin et al. 2000; Gruetter et al. 2001; Attwell and Iadecola 2002; Choi et al. 2002; Garcia-Martin et al. 2002; Henry et al. 2002; Chih and Roberts 2003), we are concerned about the assumption of rapid isotopic equilibrium between $\alpha$ ketoglutarate and glutamate. The mitochondrial membrane separates mitochondrial $\alpha$-ketoglutarate from cytosolic glutamate and mitochondrial translocases limit the rate of exchange.

In generating absolute values for the rate of synthesis of glutamate and glutamine from $\mathrm{H}^{14} \mathrm{CO}_{3}^{-}$in both the in vivo brain and in the ex vivo retina, we assumed complete equilibration of oxaloacetate and fumarate. The ${ }^{14} \mathrm{C}$ oxaloacetate precursor of glutamate and glutamine therefore was assumed to be equally labeled in the 1 and 4 position. The $\left[1-{ }^{14} \mathrm{C}\right]$ is released as ${ }^{14} \mathrm{CO}_{2}$ in the isocitrate dehydrogenase reaction and therefore all ${ }^{14} \mathrm{C}$ values were multiplied by 2 in order to compensate for this loss. If equilibration is not complete our values are overestimated, at most by a factor of 2. The assumption of complete equilibration has not been validated in the brain. The fact that the $\left[2-{ }^{13} \mathrm{C}\right]$ and $\left[3-{ }^{13} \mathrm{C}\right]$ of glutamine were different when brains were infused with $\left[1-{ }^{13} \mathrm{C}\right]$ glucose suggests that there is not complete equilibration (Gruetter et al. 1998, 2001). However, other data from brain cells and liver suggest that equilibration is substantial. In liver, complete equilibration between oxaloacetate, malate, and fumarate occurs catalyzed by the two reversible enzymes, malate dehydrogenase, and fumarase (Sterniczuk et al. 1991). Evidence in favor of significant equilibration in the $\mathrm{CNS}$ is appearance of ${ }^{14} \mathrm{C}$-pyruvate when incubating retinas (Lieth et al. 2001) or cultured astrocytes with $\mathrm{H}^{14} \mathrm{CO}_{3}^{-}$(Gamberino et al. 1997). $\mathrm{H}^{14} \mathrm{CO}_{3}^{-}$is incorporated initially into the 4-position of oxaloacetate. Decarboxylation by malic enzyme or by phosphoenolpyruvate carboxykinase to form pyruvate removes carbon at the 4 position. Therefore, no label would appear in pyruvate or in the middle carboxyl group of isocitrate without equilibration with symmetrical fumarate (Fig. 6). In primary cultures of rat brain astrocytes incubated with $\mathrm{H}^{14} \mathrm{CO}_{3}^{-}$, pyruvate was the most heavily labeled ${ }^{14} \mathrm{C}$ product (Gamberino et al. 1997), whereas in the retina it was the second most heavily labeled ${ }^{14} \mathrm{C}$ product (Lieth et al. 2001). To simplify calculations, most NMR models do not account for any equilibration (Gruetter et al. 2001). The assumptions made by various laboratories have been discussed in a recent publication (Merle et al. 2002). It will be important to determine the precise degree of equilibration at the fumarase step and whether it is influenced by metabolic state.

Rates of synthesis of glutamate and glutamine from $\mathrm{H}^{14} \mathrm{CO}_{3}^{-}$measured here likely reflect only a fraction of total brain $\mathrm{CO}_{2}$ fixation. The total rate of pyruvate carboxylation is probably higher than the anaplerotic synthesis of glutamate and glutamine. For example, a fraction of the ${ }^{14} \mathrm{C}$-oxalacetate synthesized can be metabolized by phosphoenolpyruvate carboxykinase (PEPCK) or malic enzyme to regenerate $\mathrm{CO}_{2}$ and pyruvate, leading to pyruvate cycling at the cost of one ATP/pyruvate (Cerdan et al. 1990). Likewise, some ${ }^{14} \mathrm{C}-\alpha$-ketoglutarate formed via pyruvate carboxylase will not be converted to glutamate and glutamine but will continue around the citric acid cycle (losing its $\mathrm{C}-14$ label) and the excess malate produced will be converted to pyruvate and $\mathrm{CO}_{2}$ by malic enzyme or PEPCK. This represents a substantial fraction of total $\mathrm{CO}_{2}$ fixation in agreement with previous studies (Gruetter et al. 1998, 2001; Sibson et al. 2001). Conversion of glutamate to pyruvate and lactate by cultured neonatal astrocytes has also been monitored (Sonnewald et al. 1993; Hutson et al. 1998). Conversion of ${ }^{14} \mathrm{C}$ glutamate and of $\mathrm{H}^{14} \mathrm{CO}_{3}^{-}$to ${ }^{14} \mathrm{C}$-pyruvate (pyruvate cycling) occurs in retinas (Lieth et al. 2000, 2001). 
Another goal of the present study was to evaluate the ability of the neuroactive drug gabapentin to slow the synthesis of glutamate and perhaps neurotransmission. Gabapentin is an antiseizure drug, also used to alleviate chronic pain. We have published reports previously demonstrating its ability to block de novo synthesis of glutamate, possibly by limiting the supply of branched chain amino acid for synthesis of glutamate. Others proposed that gabapentin acts by inhibiting both branched chain aminotransferases (BCATc and BCATm; Goldlust et al. 1995; Welty et al. 1995), but our studies showed that gabapentin is a specific inhibitor of the cytosolic branched chain aminotransferase (Hutson et al. 1998; Lieth et al. 2001).

No significant effect of gabapentin was detected in the present study of whole brain although its effect was evident in the retina (Lieth et al. 2001). Errante and Petroff (2003) also studied the influence of gabapentin on whole-brain metabolism. They used the same amount of gabapentin that we did $(100 \mathrm{mg} / \mathrm{kg})$ and observed a small but significant decline in glutamate mass ( $p<0.05, n=26$ rats), $2 \mathrm{~h}$ after an i.p. injection. We observed declines in ${ }^{14} \mathrm{C}$-glutamate and ${ }^{14} \mathrm{C}$-glutamine of similar magnitude but the declines were not significant. Our previous reports of inhibition of de novo synthesis by gabapentin in retinas were based on measurements of steady-state values of ${ }^{14} \mathrm{C}$-glutamate and ${ }^{14} \mathrm{C}$ glutamine. We re-examined the conclusion in the present study by carrying out a full kinetic analysis which confirmed the previous results.

The ability to quantitate anaplerosis and neuronal glutamate turnover simultaneously, demonstrated here, sets the stage for studies of neuroactive drugs on glutamate/pyruvate cycling. Thus, one can evaluate the possibility that drugs such as gabapentin ( $\mathrm{Su}$ et al. 1995; Bergey et al. 1997; Hutson et al. 1998; Rowbotham et al. 1998) and acetazolamide (Dodgson et al. 2000) and diets such as the ketogenic diet (Nordli 2002), all of which ameliorate epilepsy might exert their influence on neurotransmission by altering the anaplerotic flow of carbon from pyruvate carboxylase to glutamate. Acetazolamide inhibits pyruvate carboxylase (Hazen et al. 1997) and gabapentin inhibits the conversion of astrocytic $\alpha$-ketoglutarate to glutamate by blocking branched chain amino acid access to the branched chain aminotransferase and possibly by inhibiting the branched chain amino acid cycle via inhibition of the cytosolic branched chain aminotransferase (Hutson et al. 1998; Lieth et al. 2001).

In conclusion, the astrocytic pyruvate/glutamate cycle is a quantitatively important component of glutamate metabolism in brain and retina. Because the ${ }^{14} \mathrm{C}$ method has sufficient sensitivity it can be employed in future in vivo studies to examine the effects of dietary manipulations and drugs on specific regions of the brain, possibly by dissecting these regions, after whole animal perfusions with ${ }^{13} \mathrm{C}$ - and ${ }^{14} \mathrm{C}$ labeled metabolites.

\section{Acknowledgements}

The authors would like to acknowledge the heroic efforts of Cindy Devine in coordinating the efforts of the authors and Mac Wood for expert technical assistance at WFUSM. We would also like to acknowledge grant support from NIH R01 NS38641 (to SMH and KFL) and NIH R01NS3867 (to RG). Funding for the highresolution NMR instrumentation was provided by the University of Minnesota Medical School, NSF (BIR-961477) and the Minnesota Medical Foundation.

\section{References}

Attwell D. and Iadecola C. (2002) The neural basis of functional brain imaging signals. Trends Neurosci. 25, 621-625.

Aureli T., Di Cocco M. E., Calvani M. and Conti F. (1997) The entry of $\left[1-{ }^{13} \mathrm{C}\right]$ glucose into biochemical pathways reveals a complex compartmentation and metabolite trafficking between glia and neurons: a study by ${ }^{13} \mathrm{C}$ NMR spectroscopy. Brain Res. 765, 218-227.

Badar-Goffer R. S., Bachelard H. S. and Morris P. G. (1990) Cerebral metabolism of acetate and glucose studied by ${ }^{13} \mathrm{C}$ NMR spectroscopy. A technique for investigating metabolic compartmentation in the brain. Biochem. J. 266, 133-139.

Benjamin A. M. and Quastel J. H. (1974) Fate of L-glutamate in the brain. J. Neurochem. 23, 457-464.

van den Berg C. J. and Garfinkel D. (1971) A stimulation study of brain compartments. Metabolism of glutamate and related substances in mouse brain. Biochem. J. 123, 211-218.

Bergey G. K., Morris H. H., Rosenfeld W. et al. (1997) Gabapentin monotherapy. I. An 8-day, double-blind, dose-controlled, multicenter study in hospitalized patients with refractory complex partial or secondarily generalized seizures. The US Gabapentin Study Group 88/89. Neurology 49, 739-745.

Bergmeyer H. U. (1965) Methods of Enzymatic Analysis, 2nd edn. Academic Press, New York.

Berl S. and Clarke D. D. (1983) The metabolic compartmentation concept, in Glutamine, Glutamate and GABA in the Central Nervous System (Hertz L., Kvamne E., McGeer G. and Schousboue A., eds), pp. 205-217. Alan R. Liss, Inc., New York.

Berl S., Takagaki G., Clarke D. D. and Waelsch H. (1962) Carbon dioxide fixation in the brain. J. Biol. Chem. 237, 2570-2573.

Berl S., Clarke D. D. and Nicklas W. J. (1970) Compartmentation of citric acid cycle metabolism in brain: effect of aminooxyacetic acid, ouabain and $\mathrm{Ca}^{2+}$ on the labelling of glutamate, glutamine, aspartate and GABA by $\left[1-{ }^{14} \mathrm{C}\right]$ acetate, $\left[\mathrm{U}-{ }^{14} \mathrm{C}\right]$ glutamate and $\left[\mathrm{U}-{ }^{14} \mathrm{C}\right]$ asparate. J. Neurochem. 17, 999-1007.

Berl S., Nicklas W. J. and Clarke D. D. (1978) Glia cells and metabolic compartmentation, in Dynamic Properties of Glial Cells (Schoffeniels, E., ed.), pp. 143-149. Pergamon Press, Oxford.

Bluml S., Moreno-Torres A., Shic F., Nguy C. H. and Ross B. D. (2002) Tricarboxylic acid cycle of glia in the in vivo human brain. NMR Biomed 15, 1-5.

Bradford M. M. (1976) A rapid and sensitive method for the quantitation of microgram quantities of protein utilizing the principle of proteindye binding. Anal. Biochem. 72, 248-254.

Cerdan S., Kunnecke B. and Seelig J. (1990) Cerebral metabolism of $\left[1,2-{ }^{13} \mathrm{C}_{2}\right]$ acetate as detected by in vivo and in vitro ${ }^{13} \mathrm{C}$ NMR. J. Biol. Chem. 265, 12916-12926.

Chaudhry F. A., Lehre K. P., van Lookeren Campagne M., Ottersen O. P., Danbolt N. C. and Storm-Mathisen J. (1995) Glutamate transporters in glial plasma membranes: highly differentiated localizations revealed by quantitative ultrastructural immunocytochemistry. Neuron 15, 711-720. 
Chih C. P. and Roberts E. L. Jr (2003) Energy substrates for neurons during neural activity: a critical review of the astrocyte-neuron lactate shuttle hypothesis. J. Cereb. Blood Flow Metab. 23, 12631281.

Choi I. Y., Lei H. and Gruetter R. (2002) Effect of deep pentobarbital anesthesia on neurotransmitter metabolism in vivo: on the correlation of total glucose consumption with glutamatergic action. J. Cereb. Blood Flow Metab. 22, 1343-1351.

Cooper A. J. and Plum F. (1987) Biochemistry and physiology of brain ammonia. Physiol. Rev. 67, 440-519.

Crist G. H., Xu B., Lanoue K. F. and Lang C. H. (1998) Tissue-specific effects of in vivo adenosine receptor blockade on glucose uptake in Zucker rats. Faseb J. 12, 1301-1308.

Cruz F., Scott S. R., Barroso I., Santisteban P. and Cerdan S. (1998) Ontogeny and cellular localization of the pyruvate recycling system in rat brain. J. Neurochem. 70, 2613-2619.

Derouiche A. (1996) Possible role of the Muller cell in uptake and metabolism of glutamate in the mammalian outer retina. Vision Res. 36, 3875-3878.

Dodgson S. J., Shank R. P. and Maryanoff B. E. (2000) Topiramate as an inhibitor of carbonic anhydrase isoenzymes. Epilepsia 41, S35S39.

Errante L. D. and Petroff O. A. (2003) Acute effects of gabapentin and pregabalin on rat forebrain cellular GABA, glutamate, and glutamine concentrations. Seizure 12, 300-306.

Fitzpatrick S. M., Hetherington H. P., Behar K. L. and Shulman R. G. (1990) The flux from glucose to glutamate in the rat brain in vivo as determined by ${ }^{1} \mathrm{H}$-observed, ${ }^{13} \mathrm{C}$-edited NMR spectroscopy. J. Cereb. Blood Flow Metab. 10, 170-179.

Fonnum F. (1984) Glutamate: a neurotransmitter in mammalian brain. J. Neurochem. 42, 1-11.

Gamberino W. C., Berkich D. A., Lynch C. J., Xu B. and LaNoue K. F. (1997) Role of pyruvate carboxylase in facilitation of synthesis of glutamate and glutamine in cultured astrocytes. J. Neurochem. 69, 2312-2325.

Garcia-Martin M. L., Garcia-Espinosa M. A., Ballesteros P., Bruix M. and Cerdan S. (2002) Hydrogen turnover and subcellular compartmentation of hepatic $\left[2-{ }^{13} \mathrm{C}\right]$ glutamate and $\left[3-{ }^{13} \mathrm{C}\right]$ aspartate as detected by ${ }^{13} \mathrm{C}$ NMR. J. Biol. Chem. 277, 7799-7807.

Goldlust A., Su T. Z., Welty D. F., Taylor C. P. and Oxender D. L. (1995) Effects of anticonvulsant drug gabapentin on the enzymes in metabolic pathways of glutamate and GABA. Epilepsy Res. 22, $1-11$.

Griffin J. L., O’Donnell J. M., White L. T., Hajjar R. J. and Lewandowski E. D. (2000) Post-natal expression and activity of the mitochondrial 2-oxoglutarate/malate carrier in intact hearts. Am. $J$. Physiol. Cell Physiol. 279, C1704-C1709.

Griffin J. L., Keun H., Richter C., Moskau D., Rae C. and Nicholson J. K. (2003) Compartmentation of metabolism probed by $\left[2-{ }^{13} \mathrm{C}\right]$ alanine: improved ${ }^{13} \mathrm{C}$ NMR sensitivity using a CryoProbe detects evidence of a glial metabolon. Neurochem. Int. 42, 93-99.

Gruetter R., Seaquist E. R., Kim S. and Ugurbil K. (1998) Localized in vivo ${ }^{13} \mathrm{C}$ NMR of glutamate metabolism in the human brain: initial results at 4 tesla. Dev Neurosci. 20, 380-388.

Gruetter R., Seaquist E. R. and Ugurbil K. (2001) A mathematical model of compartmentalized neurotransmitter metabolism in the human brain. Am. J. Physiol. Endocrinol. Metab. 281, E100-E112.

Hazen S. A., Waheed A., Sly W. S., LaNoue K. F. and Lynch C. J. (1997) Effect of carbonic anhydrase inhibition and acetoacetate on anaplerotic pyruvate carboxylase activity in cultured rat astrocytes. Dev. Neurosci. 19, 162-171.

Heath D. F. and Rose J. G. (1985) ${ }^{14} \mathrm{C}$ Bicarbonate fixation into glucose and other metabolites in the liver of the starved rat under halothane anaesthesia. Metabolic channelling of mitochondrial oxaloacetate. Biochem. J. 227, 851-865.

Henry P. G., Lebon V., Vaufrey F., Brouillet E., Hantraye P. and Bloch G. (2002) Decreased TCA cycle rate in the rat brain after acute 3-NP treatment measured by in vivo $1 \mathrm{H}\left({ }^{13} \mathrm{C}\right) \mathrm{NMR}$ spectroscopy. $J$. Neurochem. 82, 857-866.

Hutson S. M., Berkich D., Drown P., Xu B., Aschner M. and LaNoue K. F. (1998) Role of branched-chain aminotransferase isoenzymes and gabapentin in neurotransmitter metabolism. J. Neurochem. 71, 863-874.

Hutson S. M., Lieth E. and LaNoue K. F. (2001) Function of leucine in excitatory neurotransmitter metabolism in the central nervous system. J. Nutr. 131, 846S-850S.

Kanai Y., Smith C. P. and Hediger M. A. (1993) The elusive transporters with a high affinity for glutamate. Trends Neurosci. 16, 365-370.

LaNoue K. F. and Tischler M. E. (1974) Electrogenic characteristics of the mitochondrial glutamate/aspartate antiporter. J. Biol. Chem. 249, 7522-7528.

LaNoue K. F., Berkich D. A., Conway M., Barber A. J., Hu L. Y., Taylor C. and Hutson S. (2001) Role of specific aminotransferases in de novo glutamate synthesis and redox shuttling in the retina. $J$. Neurosci. Res. 66, 914-922.

Lapidot A. and Gopher A. (1997) Quantitation of metabolic compartmentation in hyperammonemic brain by natural abundance ${ }^{13} \mathrm{C}$ NMR detection of ${ }^{13} \mathrm{C}-{ }^{15} \mathrm{~N}$ coupling patterns and isotopic shifts. Eur. J. Biochem. 243, 597-604.

Lebon V., Petersen K. F., Cline G. W., Shen J., Mason G. F., Dufour S., Behar K. L., Shulman G. I. and Rothman D. L. (2002) Astroglial contribution to brain energy metabolism in humans revealed by ${ }^{13} \mathrm{C}$ nuclear magnetic resonance spectroscopy: elucidation of the dominant pathway for neurotransmitter glutamate repletion and measurement of astrocytic oxidative metabolism. J. Neurosci. 22, $1523-1531$.

Lieth E., LaNoue K. F., Antonetti D. A. and Ratz M. (2000) Diabetes reduces glutamate oxidation and glutamine synthesis in the retina. The Penn State Retina Research Group. Exp. Eye Res. 70, 723730.

Lieth E., LaNoue K. F., Berkich D. A., Xu B., Ratz M., Taylor C. and Hutson S. M. (2001) Nitrogen shuttling between neurons and glial cells during glutamate synthesis. J. Neurochem. 76, $1712-1723$.

McKenna M. C., Stevenson J. H., Huang X., Tildon J. T., Zielke C. L. and Hopkins I. B. (2000) Mitochondrial malic enzyme activity is much higher in mitochondria from cortical synaptic terminals compared with mitochondria from primary cultures of cortical neurons or cerebellar granule cells. Neurochem. Int. 36, 451-459.

Martinez-Hernandez A., Bell K. P. and Norenberg M. D. (1977) Glutamine synthetase: glial localization in brain. Science 195, 13561358.

Merle M., Bouzier-Sore A. K. and Canioni P. (2002) Time-dependence of the contribution of pyruvate carboxylase versus pyruvate dehydrogenase to rat brain glutamine labelling from $\left[1-{ }^{13} \mathrm{C}\right]$ glucose metabolism. J. Neurochem. 82, 47-57.

Michaelis E. K. (1998) Molecular biology of glutamate receptors in the central nervous system and their role in excitotoxicity, oxidative stress and aging. Prog. Neurobiol. 54, 369-415.

Mimura Y., Mogi K., Kawano M., Fukui Y., Takeda J., Nogami H. and Hisano S. (2002) Differential expression of two distinct vesicular glutamate transporters in the rat retina. Neuroreport 13, 19251928.

Morris P. G., Feeney J., Cox D. W. and Bachelard H. S. (1985) ${ }^{31} \mathrm{P}$-saturation-transfer nuclear-magnetic-resonance measurements of phosphocreatine turnover in guinea-pig brain slices. Biochem. J. 227, 777-782. 
Nordli D. (2002) The ketogenic diet: uses and abuses. Neurology 58, S21-S24.

O'Donnell J. M., Doumen C., LaNoue K. F., White L. T. YuX., Alpert N. M. and Lewandowski E. D. (1998) Dehydrogenase regulation of metabolite oxidation and efflux from mitochondria in intact hearts. Am. J. Physiol. 274, H467-H476.

Patel M. S. (1989) $\mathrm{CO}_{2}$-fixing enzymes, in Neuromethods: Carbohydrate and Energy Metabolism (Boulton A. A. and Baker G. D., eds), pp. 309-340. The Humana Press, Inc., Clifton, N.J.

Rothstein J. D., Martin L., Levey A. I., Dykes-Hoberg M., Jin L., Wu D., Nash N. and Kuncl R. W. (1994) Localization of neuronal and glial glutamate transporters. Neuron 13, 713-725.

Rowbotham M., Harden N., Stacey B., Bernstein P. and Magnus-Miller L. (1998) Gabapentin for the treatment of post-herpetic neuralgia: a randomized controlled trial. Jama 280, 1837-1842.

Schmoll D., Fuhrmann E., Gebhardt R. and Hamprecht B. (1995) Significant amounts of glycogen are synthesized from 3-carbon compounds in astroglial primary cultures from mice with participation of the mitochondrial phosphoenolpyruvate carboxykinase isoenzyme. Eur. J. Biochem. 227, 308-315.

Schoolwerth A. C., Nazar B. L. and Lanoue K. F. (1977) The role of glutamate metabolism in ammonia formation by rat kidney mitochondria. Curr. Probl. Clin. Biochem. 8, 265-272.

Shank R. P., Bennett G. S., Freytag S. O. and Campbell G. L. (1985) Pyruvate carboxylase: an astrocyte-specific enzyme implicated in the replenishment of amino acid neurotransmitter pools. Brain Res. 329, 364-367.

Shank R. P., Leo G. C. and Zielke H. R. (1993) Cerebral metabolic compartmentation as revealed by nuclear magnetic resonance analysis of $\mathrm{D}-\left[1-{ }^{13} \mathrm{C}\right]$ glucose metabolism. J. Neurochem. 61, 315323.

Shousboe U., Westergaard N., Sonewald U., Petersen S. B., Huang R., Peng L. and Hertz L. (1993) Glutamate and glutamine metabolism and compartmentation in astrocytes. Dev. Neurosci. 15, 359366.

Sibson N. R., Dhankhar A., Mason G. F., Behar K. L., Rothman D. L. and Shulman R. G. (1997) In vivo ${ }^{13} \mathrm{C}$ NMR measurements of cerebral glutamine synthesis as evidence for glutamate/glutamine cycling. Proc. Natl Acad. Sci. USA 94, 2699-2704.

Sibson N. R., Dhankhar A., Mason G. F., Rothman D. L., Behar K. L. and Shulman R. G. (1998) Stoichiometric coupling of brain glucose metabolism and glutamatergic neuronal activity. Proc. Natl Acad. Sci. USA 95, 316-321.

Sibson N. R., Mason G. F., Shen J., Cline G. W., Herskovits A. Z., Wall J. E., Behar K. L., Rothman D. L. and Shulman R. G. (2001) In vivo ${ }^{13} \mathrm{C} \mathrm{NMR}$ measurement of neurotransmitter glutamate cycling, anaplerosis and TCA cycle flux in rat brain. J. Neurochem. 76, 975-989.

Sonnewald U., Westergaard N., Petersen S. B., Unsgard G. and Schousboe A. (1993) Metabolism of $\left[\mathrm{U}^{13}{ }^{13} \mathrm{C}\right]$ glutamate in astrocytes studied by ${ }^{13} \mathrm{C}$ NMR spectroscopy: incorporation of more label into lactate than into glutamine demonstrates the importance of the tricarboxylic acid cycle. J. Neurochem. 61, $1179-1182$.

Sterniczuk A., Hreniuk S., Scaduto R. C. Jr and LaNoue K. F. (1991) The mechanism of $\mathrm{Ca}^{2+}$-related control of gluconeogenesis in perfused liver. Eur J. Biochem. 196, 143-150.

Strzelecki T., Strzelecka D., Koch C. D. and LaNoue K. F. (1988) Sites of action of glucagon and other $\mathrm{Ca}^{2+}$ mobilizing hormones on the malate aspartate cycle. Arch. Biochem. Biophys. 264, 310-320.

Su T. Z., Lunney E., Campbell G. and Oxender D. L. (1995) Transport of gabapentin, a gamma-amino acid drug, by system L-alpha-amino acid transporters: a comparative study in astrocytes, synaptosomes, and CHO cells. J. Neurochem. 64, 2125-2131.
Takahashi M., Billups B., Rossi D., Sarantis M., Hamann M. and Attwell D. (1997) The role of glutamate transporters in glutamate homeostasis in the brain. J. Exp Biol. 200, 401-409.

Torgner I. and Kvamme E. (1990) Synthesis of transmitter glutamate and the glial-neuron inter-relationship. Mol. Chem. Neuropathol 12, $11-17$.

Vogel R., Jennemann G., Seitz J., Wiesinger H. and Hamprecht B. (1998) Mitochondrial malic enzyme: purification from bovine brain, generation of an antiserum, and immunocytochemical localization in neurons of rat brain. J. Neurochem. 71, 844-852.

Waelsch H., Berk S., Rossi C. A., Clarke D. D. and Purpura D. P. (1964) Quantitative aspects of $\mathrm{CO}_{2}$ fixation in mammalian brain in vivo. J. Neurochem. 11, 717-728.

Welty D. F., Schielke G. P. and Rothstein J. D. (1995) Potential treatment of amyotrophic lateral sclerosis with gabapentin: a hypothesis. Ann. Pharmacother. 29, 1164-1167.

Yu X., White L. T., Doumen C., Damico L. A., LaNoue K. F., Alpert N. M. and Lewandowski E. D. (1995) Kinetic analysis of dynamic ${ }^{13} \mathrm{C}$ NMR spectra: metabolic flux, regulation, and compartmentation in hearts. Biophys. J. 69, 2090-2102.

Williamson J. R. and Corkey B. E. (1969) Assays of intermediates of the citric acid cycle and related compounds by fluorometric enzyme methods, in Methods of Enzymology (Lowenstein J. M., ed.), pp. 435-513. Academic Press, New York.

\section{Appendix}

From standard equations of label incorporation and efflux, such as Equation 1 in Gruetter et al. (1998), relationships between the label incorporation into metabolites and metabolic fluxes can be derived. Restating Equation 1 from Gruetter et al. (1998) in a simplified form, where $V_{\text {out }}$ is equal to the sum of all fluxes by which label leaves the pool $P$, gives

$$
\frac{\mathrm{d}^{13} \mathrm{P}}{\mathrm{dt}}(\mathrm{t})=\sum_{\mathrm{i}=1}^{\mathrm{n}} \mathrm{V}_{\mathrm{i}} \frac{{ }^{13} \mathrm{~S}_{\mathrm{i}}(\mathrm{t})}{\mathrm{S}_{\mathrm{i}}}-\mathrm{V}_{\text {out }} \frac{{ }^{13} \mathrm{P}(\mathrm{t})}{\mathrm{P}}
$$

For the present study and derivation of the analytical form of (1) it shall be assumed that the precursor pool labels instantaneously at $t=0$ :

$$
\frac{{ }^{13} \mathrm{~S}_{\mathrm{i}}(\mathrm{t})}{\mathrm{S}_{\mathrm{i}}}=\alpha_{\mathrm{i}} \text { for } \mathrm{t}>0
$$

where $\alpha_{i}$ is the steady-state isotopic enrichment of the precursor $\mathrm{S}_{\mathrm{i}}$. A general solution for (A1) shall be attempted with

$$
{ }^{13} \mathrm{P}(\mathrm{t})={ }^{13} \mathrm{P}^{\infty}+\mathrm{A}_{0} \mathrm{e}^{-\mathrm{kt}}
$$

where ${ }^{13} \mathrm{P}^{\infty}$ represents the amount of steady-state labeling of the Product $\mathrm{P}$. Taking the derivative with respect to time $t$ gives

$$
\frac{\mathrm{d}^{13} \mathrm{P}}{\mathrm{dt}}(\mathrm{t})=-\mathrm{kA}_{0} \mathrm{e}^{-\mathrm{kt}}
$$

Conversely, substituting equations (A2) and (A3) into (A1) results in 


$$
\frac{\mathrm{d}^{13} \mathrm{P}}{\mathrm{dt}}(\mathrm{t})=\sum_{\mathrm{i}=1}^{\mathrm{n}} \mathrm{V}_{\mathrm{i}} \alpha_{\mathrm{i}}-\mathrm{V}_{\text {out }} \frac{{ }^{13} \mathrm{P}^{\infty}+\mathrm{A}_{0} \mathrm{e}^{-\mathrm{kt}}}{\mathrm{P}}
$$

Equating the right hand side of (A4) and (A5) results in the following relationships:

$$
\frac{{ }^{13} \mathrm{P}^{\infty}}{\mathrm{P}}=\frac{\sum_{\mathrm{i}=1}^{\mathrm{n}} \mathrm{V}_{\mathrm{i}} \boldsymbol{\alpha}_{\mathrm{i}}}{\mathrm{V}_{\text {out }}}
$$

and

$$
\mathrm{k}=\frac{\mathrm{V}_{\mathrm{out}}}{\mathrm{P}}
$$

with the starting condition ${ }^{13} \mathrm{P}(0)=0$ resulting in

$$
\mathrm{A}_{0}=-{ }^{13} \mathrm{P}^{\infty}=-\mathrm{P} \frac{\sum_{\mathrm{i}=1}^{\mathrm{n}} \mathrm{V}_{\mathrm{i}} \alpha_{\mathrm{i}}}{\mathrm{V}_{\text {out }}}
$$

when substituting (A6).

From (A6) it follows that if only one precursor $S_{j}$ is labeled, we can calculate the flux from that precursor to the product, as follows: Assume $\alpha_{i}=0$ for $\mathrm{i} \neq \mathrm{j}$, and substituting (A7) into (A6), results in

$$
\mathrm{V}_{\mathrm{j}}=\frac{\mathrm{k}^{13} \mathrm{P}^{\infty}}{\alpha_{\mathrm{j}}}
$$

The nomenclature for ${ }^{14} \mathrm{C}$ labeling is derived from these equations by replacing the superscript 13 with *. In the paper,
$\mathrm{A}$ and $\mathrm{B}$ represent the product pool size $\mathrm{P}$ (mass) of glutamate and glutamine, respectively.

In this case, knowing the relative precursor isotopic enrichment (A2), $\alpha_{j}$, and the steady-state labeling of the product, as well as the product turnover time, the specific flux $V_{j}$ can be calculated. In practice, $\alpha_{j}$ is the most difficult parameter to define experimentally. For example, in the present study $\alpha_{\mathrm{j}}$ is unknown for the anaplerotic fixation of $\mathrm{CO}_{2}$, because the labeling of the amino acids is diluted by labeling from the glial TCA cycle (due to acetyl-CoA oxidation in astrocytes) and from the lower enrichment of neuronal glutamate by the action of the glutamate/glutamine cycle. In this and similar cases, however, assuming the precursor enrichment, e.g. that of plasma $\mathrm{H}^{14} \mathrm{CO}_{3}{ }^{-}$, can be used for obtaining lower bounds of the estimated flux, the calculation is possible. To correct for the dilution of the TCA cycle intermediates by oxidation of glucose and other energy substrates, dilution of the $\mathrm{H}^{14} \mathrm{CO}_{3}^{-}$labeling of the glial citrate pool, which occurs at the rate $\mathrm{V}_{\mathrm{g}}$ (Gruetter et al. 2001), this apparent anaplerotic flux has to be multiplied by $\left[1+\mathrm{V}_{\mathrm{g}} / \mathrm{V}_{\mathrm{PC}}\right]$. Interestingly, as glutamine cannot be labeled more than fully by $\mathrm{H}^{14} \mathrm{CO}_{3}^{-}$, the relative enrichment of glutamine $\mathrm{B} * / \mathrm{B}$ (normalized relative to that of $\mathrm{H}^{14} \mathrm{CO}_{3}{ }^{-}$, Table 1) provides an upper limit for $\mathrm{V}_{\mathrm{g}} / \mathrm{V}_{\mathrm{PC}}: \mathrm{V}_{\mathrm{g}} / \mathrm{V}_{\mathrm{PC}}<\mathrm{B} /$ $\mathrm{B}^{*}-1$. Another correction factor needs to deal with the dilution from neuronal glutamate, which further indicates that the present fluxes for anaplerosis underestimate the true rate of anaplerosis. 